\title{
COMPARATIVE ANALYSIS OF EXPONENTIAL SMOOTHING MODELS TO TOURISTS' ARRIVALS IN SERBIA
}

\author{
Nataša Papić-Blagojević1, Aleksandra Vujko², Tamara Gajić3
}

\begin{abstract}
Summary
Seasonality is one of the main aspects affecting tourism. Considering the rapid increase in international tourism demand over the last few decades, predictions of future trends of tourism demand are of particular importance for the Government and the economy. We analyze the seasonality of tourist presence in different cities in Serbia. In this paper, the exponential smoothing models have been applied on the data that was taken from Republic Statistical Office (RSO). The research was conducted on monthly data relating to the number of overnight stays in Belgrade, Novi Sad and Niš during the period from January 2000 to December 2013. The precision of the obtained predictions is determined by comparing the RMSE and BIC precision measures. Based on the selected data,forecasting was made and it is concluded that the selected models correspond to the observed data very well.
\end{abstract}

Key words: time series forecasting, exponential smoothing models, tourist arrivals, Serbia JEL: Q11

\section{Introduction}

Tourism is attributed to the "power" to foster socio-economic and demographic development. There are numerous examples of entire regions where tourism is the dominant or unifying activity (Vujko, Gajić, 2014). The tourism industry is one of the most crucial sectors for a thriving economy as it accounts for a large part of some countries' Growth Domestic Product (GDP) and employment figures. Tourism is characterized by large variations in numbers on a yearly basis and, as a result, predicting future arrivals is a very difficult task (Gounoploulos et al., 2012). According to Nunkoo and Smith they involve comparative economic advantages in relation to the regions which do not develop tourism. It is therefore not surprising when we refer to tourism as a development catalyst (Nunkoo, Smith, 2013). These effects are present in our experiential heritage, so they are considered logical, almost axiomatic. They clearly

1 Nataša Papić-Blagojević, Ph.D., Lecturer, Novi Sad Business School, Serbia, Vladimir PerićValter Street, No 4, Phone: +381 6417368 39, E-mail: npapic.blagojevic@gmail.com

2 Aleksandra Vujko, Ph.D., Lecturer, Novi Sad Business School, Vladimir Perić Valter Street No. 4, Novi Sad, Serbia, Phone: +381 6491426 45, E-mail: aleksandravujko@yahoo.com

3 Tamara Gajić, Ph.D., Professor of professional studies, Novi Sad Business School, Vladimir PerićValter Street No. 4, Novi Sad, Serbia, Phone: +381 63565 544, E-mail: gajic tamara@yahoo.com 
explain why tourism is recognized as an "industry-initiative" of demographic and economic recovery, but not sufficient for generalization according to which any attempt to tourism development necessarily results in prosperity (Vujko, Gajić, 2014).

The most important urban tourist destinations in Serbia are the main administrative centers, Belgrade, Novi Sad and Niš. Thanks to the favorable tourist and geographical position, natural values in the area, a rich cultural and historical heritage and a solid material basis, these urban centers develop various forms of tourist movements. Therefore, it is necessary to make the analysis of tourist turnover, in order to highlight the main directions of tourism development.

Over the past 40 years, time-series models adopted mostly ARIMA models for tourism demand forecasting, followed by Naïve 1, Naïve 2, exponential smoothing models, and simple autoregressive models (Lin, Lee, 2013; Song, Li, 2008). In order to find the best fitting forecast model for the observed data, authors choose exponential smoothing models.

For the purpose of research, the exponential smoothing models have been applied to the historical data of the number of tourists in the three cities. Our aim is to provide the empirical evidence that is the use of exponential smoothing model is useful for generating accurate prediction intervals, in practice. The autoregressive integrated moving average (ARIMA) model has excellent natural statistical characteristics and is the most popular (Sudheer, Suseelatha, 2015). The results are compared based on the Bayesian Information Criterion (BIC) and Root Mean Square Error (RMSE) as accuracy measures and it was concluded that the chosen models correspond to the selected data very well. The used data were taken from the Tourism Bureau of Republic of Serbia (RZS) and the research was conducted on monthly data relating to the number of tourists in Novi Sad, Belgrade and Niš during the period from January 2000 to December 2013. We have found that the analysis of an exponential smoothing model perform most desirably, especially when the forecast horizon is long.

\section{Literature review}

According to Songa et al. (2011), seasonality affects tourism in various different ways and is responsible for difficulties in gaining access to capital, high risks of investment and business failures, the ineffective utilisation of resources and facilities, and difficulties in maintaining a consistent service quality. Seasonality can be defined as "the temporal imbalance in the phenomenon of tourism, which may be expressed in terms of dimensions of such elements as numbers of visitors, expenditure of visitors, traffic on highways and other forms of transportation, employment and admissions to attractions", (Butler, 1994; Cuccia, Rizzo, 2011). According to Cuccia and Rizzo (2011), the number of tourists is a measure of the quantitative dimension of the demand, while their expenditures measure the economic value of the demand for the tourism destination.

Exponential smoothing methods are forecasting techniques which are used widely for the analysis of univariate time series, due to their simplicity and robustness as automatic forecasting procedures (Valet et al., 2011). They originated in the work of Brown and Holt (Brown, 1959; Holt, 1957), but among the most widely known and used forecasting 
techniques for seasonal time series are the methods proposed by Winters (1960), one for additive seasonality (additive Holt-Winters method) and one for multiplicative seasonality (multiplicative Holt-Winters method), (Koehler et al., 2001).

The exponential smoothing models use three parameters in forecasting: parameter $\alpha$ as weighting or smoothing parameter of level, parameter $\gamma$ as weighting parameter of trend and parameter $\delta$ as weighting parameter for seasonal components (Cho, 2003). Winters' additive and multiplicative exponential smoothing models incorporate these three parameters. The former model is appropriate for a series with a linear trend and a seasonal effect that does not depend on the level of the series. The latter model is appropriate for the same type of trend, but when the seasonal effect does depend on the level of the series (Coshall, 2009).

According to Zhi-Peng et al. (2008), the major advantage of exponential smoothing methods is that they are simple, intuitive, and easily understood. Generally, exponential smoothing is regarded as an inexpensive technique that gives good forecast in a wide variety of applications. In addition, data storage and computing requirements are minimal, which makes exponential smoothing suitable for real-time application (Zhi-Peng et al., 2008). The major disadvantage of exponential smoothing methods derives from its basic premise about the model: the level of time series should fluctuate about a constant level or change slowly over time. When the time series takes on an obvious trend, even adaptive exponential smoothing methods will fail to give good forecasting.

\section{Research Methodology}

Exponential smoothing models have been shown to generate accurate forecasts of tourism demand. These methods use weighted values of past observations to generate forecasts. The weights decline exponentially over time, since the most recent data are considered to be more influential on forecasts than are older observations (Coshall, Charlesworth, 2011). Exponential smoothing model considers the error, trend and seasonal components in choosing the best model by optimizing initial values and parameters (Hassani et al., 2015).

Exponential smoothing models can be seasonal or nonseasonal. Which of these models would be applied depends on the seasonal or nonseasonal character of the observed data. In this paper is confirmed that the chosen series Number of tourists - Novi Sad, Belgrade and Niš have a seasonal character, so that's the reason why the three seasonal exponential smoothing models: simple seasonal, Winters additive and Winters multiplicative models, were applied and the results compared. On that way, the seasonal character of the observed series and trend component are putted at the same place.

Single (or simple) exponential smoothing (SES) is the earliest known exponential smoothing technique. It requires the current level of the series to be estimated, which then forms the forecast of the series (Lim, McAleer, 2001). Exponential smoothing is usually based on the premise that the level of time series should fluctuate about a constant level or change slowly over time. Under such a premise, the travel time series $\gamma(t)$ can be described by 


$$
\gamma(t)=\beta(t)+\varepsilon(t)
$$

where $\beta(t)$,takes a constant at time $t$ and may change slowly over time, $\varepsilon(t)$ ls a random variable and is used to describe the effect of stochastic fluctuation. Sometimes, it is necessary to change the smoothing parameter $\alpha$ used in exponential smoothing when the rate at which $\beta$ changes over time changes. This suggests that an adaptive smoothing parameter (AES) would produce improved forecasts.

Models with seasonality present can be additive, where the seasonal effect does not depend on the level of the time series or multiplicative, where such a dependency does exist (Coshall, Charlesworth, 2011). There are many forms of exponential smoothing methods of which the Holt-Winters family of exponential smoothing methods is the one most commonly used. The Winters models are using three parameters, $\alpha, \delta$, and $\gamma$ for forecasting. The parameter $\alpha$ is weighting or smoothing parameter of level, parameter $\gamma$ is weighting parameter of trend and parameter $\delta$ as weighting parameter for seasonal components. The Winters model is given as follows (Cho, 2003):

$$
\widehat{Y}_{t+1}(t)=[a(t)+b(t)] \cdot S n_{n+1}(t+1-L)+\varepsilon_{t},
$$

where

\section{$\hat{P}_{t+1}(t)$ is the forecast for the next time period, $t+1$ :}

$a(t)$ is the smoothed estimated for the level at time period $t$;

\section{$b(t)$ is the smoothed estimate for the slope at time period $t$,}

$S n_{n+1}(t+1-L)$ is the smoothed estimate for the $(t+1)$ th season made at time period $t+1-L$ :

\section{$L$ is the periodicity of the seasonality;}

\section{$\varepsilon_{t}$, is the forecast error at period $t$.}

All three models where applied to series Number of tourists - Novi Sad, Belgrade and Niš. According to BIC and RMSE precision measures, it was concluded that Winters multiplicative model outperforms two others for series Novi Sad and Niš. On the other hand, the Simple Seasonal model has a better performance for series Belgrade.

\section{Results and discussion}

Most visitor arrivals are affected by the economic environment and seasonal factors such as weather or public holidays. If a seasonal factor exists in a series, one would expect large fluctuations between months. In contrast, the number of visitors may drop during the autumn season when they have fewer holidays (Cho, 2003). The presence of seasonal effects is calculated for observed data and based on that values is concluded that the seasonal factors are higher from April to October for all series.

The series Number of tourists - Novi Sad, Belgrade and Niš is shown in the Figure 1. where 
it can be seen that the inflow of tourists in Belgrade is significantly higher than the inflow of tourists in Novi Sad and Niš.

Figure 1. Number of tourists in Novi Sad, Belgrade and Niš (January, 2000 - December, 2013)

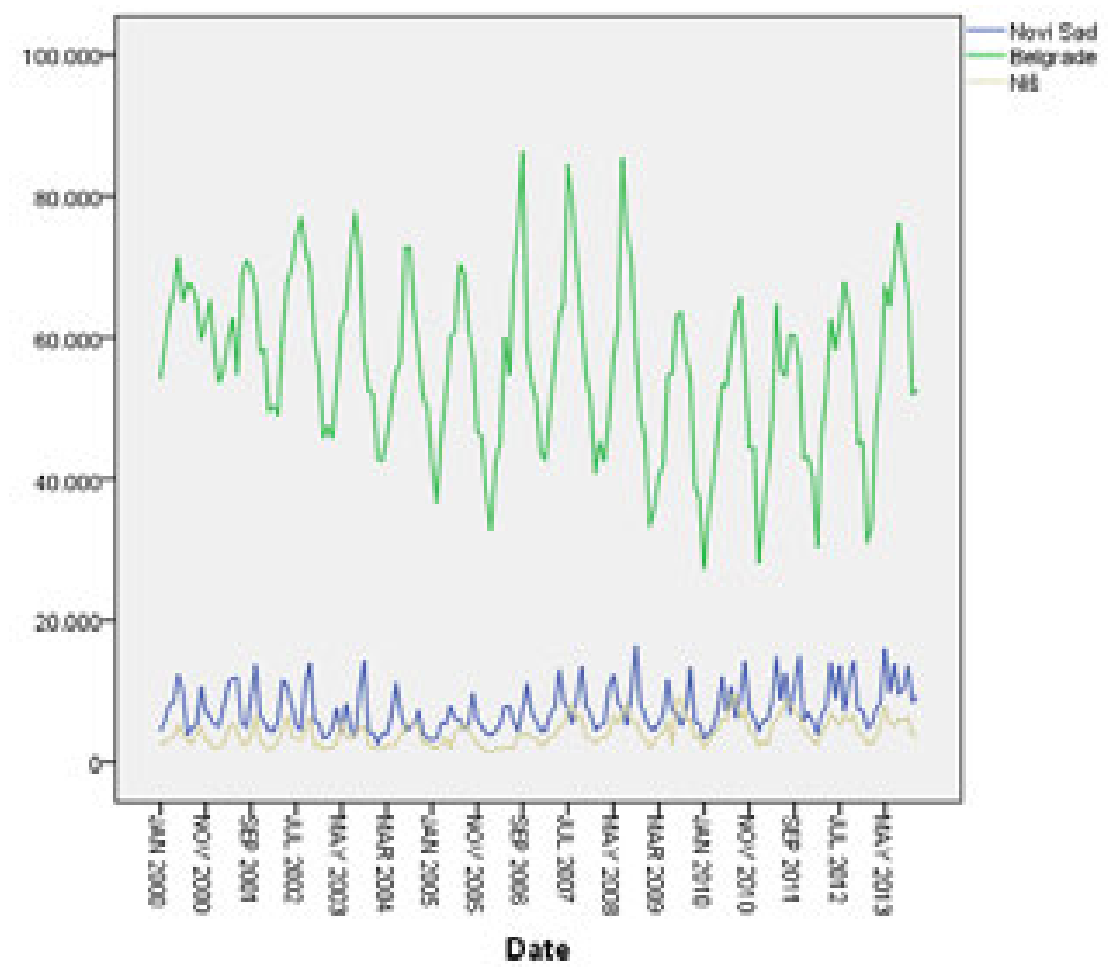

Source: Authors' research

This observation is also confirmed in the Table 1. by comparison of mean value in these three cities. Precisely, the mean value in Belgrade is few times greater than the mean value in Novi Sad and Niš.

Table 1. Basic statistics

\begin{tabular}{|l|r|r|r|}
\hline & \multicolumn{1}{|c|}{ Novi Sad } & \multicolumn{1}{c|}{ Belgrade } & \multicolumn{1}{c|}{ Niš } \\
\hline Mean & $7,511.71$ & $56,111.06$ & $4,179.55$ \\
\hline $\mathrm{N}$ & 168 & 168 & 168 \\
\hline Std. Deviation & $3,201.743$ & $12,102.676$ & $1,845.750$ \\
\hline Maximum & 16,543 & 86,205 & 9,352 \\
\hline Minimum & 2,747 & 27,389 & 1,260 \\
\hline Skewness & 0,866 & $-0,052$ & 0,790 \\
\hline Kurtosis & $-0,131$ & $-0,347$ & 0,029 \\
\hline Sum & $126,196.7$ & $942,665.8$ & 702,164 \\
\hline
\end{tabular}

Source: Own calculations based on data from Republic Statistical Office 
From the Figure 1 it could be seen the presence of seasonal effects on the observed data and the values of seasonal factors further confirm that pattern in Table 2. They are, as usual, expressed in percentage and, based on this values, we can conclude that in all series seasonal factors are higher from April to October.

Table 2. Seasonal Factors

\begin{tabular}{|l|r|r|r|}
\hline Period & \multicolumn{3}{|c|}{ Seasonal Factor (\%) } \\
\hline & Novi Sad & Belgrade & Niš \\
\hline 1 & 58,5 & 71,2 & 52,2 \\
\hline 2 & 60,7 & 71,7 & 58,9 \\
\hline 3 & 77,4 & 82,7 & 93,9 \\
\hline 4 & 106,5 & 93,4 & 125,7 \\
\hline 5 & 154,9 & 109,2 & 110,2 \\
\hline 6 & 112,5 & 109,0 & 123,3 \\
\hline 7 & 100,0 & 123,9 & 141,7 \\
\hline 8 & 71,3 & 128,7 & 126,4 \\
\hline 9 & 116,4 & 121,4 & 139,4 \\
\hline 10 & 175,7 & 108,4 & 79,7 \\
\hline 11 & 87,5 & 91,5 & 74,8 \\
\hline 12 & 78,6 & 88,9 & \\
\hline
\end{tabular}

Source: Own calculations based on data from Republic Statistical Office

It could be also noticed that the seasonal factors for series Novi Sad in May and October are extremly higher than in other periods because its values are $154,9 \%$ and $175,7 \%$. That can be explained by the fact that Novi Sad is a frequent destination for school excursions from the country and surroundings, which normally take place in spring or fall, and at the same time it is a period of maintenance different events, which attract both domestic and foreign tourists (Gajić et al., 2015).

Models with seasonality present can be additive, where the seasonal effect does not depend on the level of the time series or multiplicative, where such a dependency does exist (Coshall, Charlesworth, 2011). The results of applied Simple Seasonal and Winters additive and multiplicative models are shown in Table 3.

Table 3. Model statistics

\begin{tabular}{|c|c|c|c|}
\hline Model & Simple Seasonal & Winters Additive & Winters Multiplicative \\
\hline & \multicolumn{3}{|c|}{ Novi Sad-Model_1 } \\
\hline Normalized BIC & 14,706 & 14,742 & 14,651 \\
\hline \multirow[t]{2}{*}{ RMSE } & $1,514.134$ & $1,518.351$ & $1,450.376$ \\
\hline & \multicolumn{3}{|c|}{ Belgrade-Model_2 } \\
\hline Normalized BIC & 16,897 & 16,930 & 17,063 \\
\hline \multirow[t]{2}{*}{ RMSE } & $4,528.046$ & $4,534.171$ & $4,844.161$ \\
\hline & \multicolumn{3}{|c|}{ Niš-Model_3 } \\
\hline Normalized BIC & 13,866 & 13,904 & 13,831 \\
\hline RMSE & 994,728 & 998,344 & 962,642 \\
\hline
\end{tabular}

Source: Own calculations based on data from Republic Statistical Office 
Table 3 reports the normalized BIC and RMSE results for all three models. These are very popular precision measures for forecasting accuracy. Based on both criterions, Winters Multiplicative model outperforms Simple Seasonal and Winters Additive model for series Novi Sad and Niš. On the other hand, according to BIC and RMSE criterion, Simple Seasonal model is the best choice for series Belgrade.

Based on the results reported in Table 3, we estimated exponential smoothing model parameters for the models that were the most precise according to BIC and RMSE accuracy measures and the results are shown in Table 4.

Table 4. Exponential smoothing model parameters

\begin{tabular}{|l|l|r|}
\hline Model & $\alpha$ (Level) & \multicolumn{1}{|c|}{ Estimate } \\
\cline { 2 - 3 } Novi Sad-Model_1 & $\gamma$ (Trend) & 0,189 \\
\cline { 2 - 3 } & $\delta$ (Season) & 0,014 \\
\hline \multirow{4}{*}{ Belgrade-Model_2 } & $\alpha$ (Level) & 0,430 \\
\hline \multirow{4}{*}{ Niš-Model_3 } & $\gamma$ (Trend) & 0,700 \\
\cline { 2 - 3 } & $\delta$ (Season) & 0,000 \\
\cline { 2 - 3 } & $\alpha$ (Level) & $0,814 \mathrm{E}-005$ \\
\hline & $\gamma$ (Trend) & 0,004 \\
\cline { 2 - 3 } & $\delta$ (Season) & 0,558 \\
\hline
\end{tabular}

Source: Own calculations based on data from Republic Statistical Office

In Table 4 we can see values for all three smoothing parameters, $\alpha, \gamma$ and $\delta$. For the series Novi Sad, the value of the parameter $\alpha$ is low at 0,189 and it indicates that the observed series is quite stable during the period. Trend value $\gamma$ is also low and we can conclude that the slope of the trend line is fairly constant. Because the large values for $\gamma$ give more weight to recent estimates of the trend component and small values giving more weight to historical estimates of the trend component (Coshall, 2009), we can conclude that for all observed series historical values are more important.

Seasonal effects are explained by third parameter $\delta$. Its value of 0,430 indicates that the seasonal effects are more pronounced. Similar explanation we could also give for series Niš, because the value of parameter level is quite low and the value of seasonal parameter is high. Actually, large values of $\delta$ give most weight to the most recent estimates of the seasonal component and small values give more weight to historical estimates of this component (Coshall, 2009). Table 4 reports higher values of parameter $\delta$ for series Novi Sad and Niš and lower value for series Belgrade.

The series Belgrade differences from other two series because its value of level parameter $\alpha$ is high (0,700). High value indicates the fluctuation of arrivals is large (Cho, 2003) and also, if $\alpha$ is close to one, the new forecast would equal the previous forecast and a substantial proportion of the most recent forecast error; if $\alpha$ is close to zero, the new forecast would equal the previous forecast with little influence from the most recent forecast error (Lim, McAleer, 
2001). Based on the selected models, Winters multiplicative for series Novi Sad and Niš and Simple Seasonal for series Belgrade, forecasting was made. The results are shown in the Figure 2, where we can conclude that the chosen models fit well to the observed data.

Figure 2. Observed and fit values for the series Number of tourists in Novi Sad, Belgrade and Niš (January, 2000 - December, 2013)

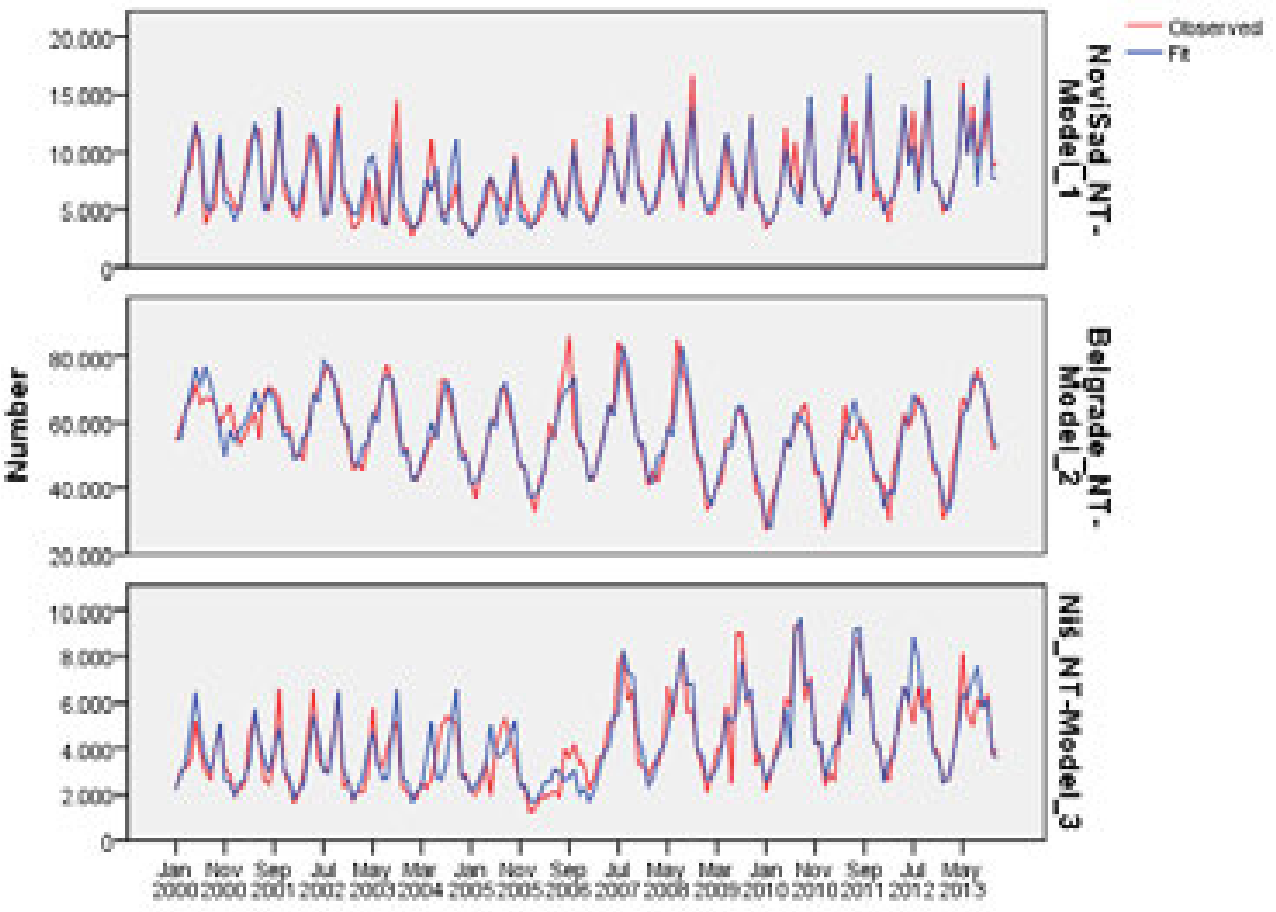

\section{Date}

Source: author research

\section{Conclusion}

Positive economic effects of tourism development are reflected in many ways (de Oliveira, 2003). The money spent by foreign tourists in the country has a multiple effect, thus generating multiple effects on national income and employment. Spending by foreign tourists causes the initial impetus that begins the multiplier sequence (Vujko, Gajić, 2014).

The validity of forecasting rests on the assumption that the pattern that has been identified will continue in the future. A forecasting technique cannot be expected to give good predictions unless this assumption is valid. If the data pattern that has been identified does not persist in the future, this indicates that the forecasting technique being used is likely to produce inaccurate predictions (Zhi-Peng et al., 2008).

This paper deals with linear innovations state space models only, as exponential smoothing models with multiplicative seasonal indexes need an alternative Bayesian analysis. The 
results obtained from the prediction of real correlated time series are encouraging. With the use of the exponential smoothing model proposed in this paper, it is possible to improve the forecast accuracy with respect to the homogeneous multivariate model when the assumption of a common structure for the univariate models is inappropriate.

\section{References}

1. Butler, R. W. (1994): Seasonality in tourism: issues and implication, In A. V. Seaton (Ed.), Tourism: A state of the art, Chichester, UK: Wiley, pp. 332-339.

2. Brown, R. G. (1959): Statistical forecasting for inventory control, New York: McGraw-Hill.

3. Cuccia, T. and Rizzo, I. (2011): Tourism seasonality in cultural destinations: Empirical evidence from Sicily, Tourism Management, Vol. 32, pp. 589-595.

4. Cho, V. (2003): A comparison of three different approaches to tourist arrival forecasting, Tourism Management, Vol. 24, pp. 323-330.

5. Coshall, J.T. (2009): Combining volatility and smoothing forecasts of UK demand for international tourism, Tourism Management, Vol. 30, pp. 495-511.

6. Coshall, J.T. and Charlesworth, R. (2011): A management orientated approach to combination forecasting of tourism demand, Tourism Management, Vol. 32, pp. 759-769.

7. de Oliveira, J. A. P. (2003): Government responses to tourism development: Three Brazilian case studies, Tourism Management, Vol. 24, pp. 97-110.

8. Gajić, T., Vujko, A. and Papić Blagojević, N. ( 2015): Forecasting tourist arrivals in Novi Sad by using the ARIMA model, Second International Conference "Higher education in function of development of tourism in Serbia and Western Balkans", In Proceedings, Business Technical College, Užice, pp. 137-146.

9. Gounoploulos, D., Petmezas, D. and Santamaria, D. (2012): Forecasting tourist arrivals in Greece and the impact of macroeconomic shocks from the countries of tourists'origin, Annals of Tourism Research, Vol. 39, Issue 2, pp. 641-666.

10. Hassani, H., Webster, A., Silva, E.S. and Heravi, S. (2015): Forecasting U.S. Tourist arrivals using optimal Singular Spectrum Analysis, Tourism Management, Vol. 46, pp. 322-335.

11. Holt, C. C. (1957): Forecasting trends and seasonals by exponentially weighted averages, O.N.R. Memorandum 52/1957, Carnegie Institute of Technology.

12. Koehler, A.B., Snyder, D.R., Ord, K.J. (2001): Forecasting models and prediction intervals for the multiplicative Holt-Winters method, International Journal of Forecasting, Vol. 17, Issue 2, pp. 269-286.

13. Lim, C. and McAleer, M. (2001): Forecasting tourist arrivals, Annals of Tourism Research, Vol. 28, Issue 4, pp. 965-977.

14. Lin, C.J. and Lee, T.S. (2013): Tourism Demand Forecasting: Econometric Model based on Multivariate Adaptive Regression Splines, Artificial Neural Network and Support Vector Regression, Advances in Management \& Applied Economics, Vol. 3, Issue 6, pp. 1-18.

15. Nunkoo, R., and Smith, S. L. J. (2013): Political economy of tourism: Trust in 
government actors, political support, and their determinants, Tourism management, Vol. 36, pp. 120-132.

16. Song, H. and Li, G. (2008): Tourism demand modelling and forecasting-A review of recent research, Tourism Management, Vol. 29, pp. 203-220.

17. Songa, H., Lib, G., Wittb, S.F., Athanasopoulosc, G. (2011): Forecasting tourist arrivals using time-varying parameter structural time series models, International Journal of Forecasting, Vol. 27, pp. 855-869.

18. Sudheer, G., Suseelatha, A. (2015): Short term load forecasting using wavelet transform combined with Holt-Winters and weighted nearest neighbor models. International Journal of Electrical Power \& Energy Systems, Vol. 64, pp. 340-346.

19. Vallet, A.C., Bermudes, J.D. and Vercher, E. (2011): Forecasting correlated time series with exponential smoothing models, International Journal of Forecasting, Vol. 27, pp. 252-266.

20. Vujko, A., Gajić, T. (2014): The gouverment policy impact on economic development of tourism, Ekonomika poljoprivrede., Vol. 61, Issue 3, pp. 789-804.

21. Winters, P. R. (1960): Forecasting sales by exponentially weighted moving average, Management Science, Vol. 6, pp. 324-342.

22. Zhi-Peng, L., Hong, Y., Yun-Cai, L., Fu-Qiang, L. (2008): An Improved Adaptive Exponential Smoothing Model for Short-term Travel Time Forecasting of Urban Arterial Street, Acta Automatica Sinica, Vol. 34, No. 11, pp. 1404-1409. 


\title{
UPOREDNA ANALIZA MODELA PREDVIĐANJA TURISTIČKOG PROMETA U SRBIJI
}

\author{
Nataša Papić-Blagojevič ${ }^{4}$, Aleksandra Vujko ${ }^{5}$, Tamara Gajićc
}

Rezime

Sezonalnost predstavlja jedan od važnijih aspekata turizma, koji vrši direktan uticaj na tu privrednu delatnost. S obzirom na povaćanje međunarodnih turističkih tokova u poslednjim decenijama, predviđanje budućih turističkih tokova i prevazilaženje sezonalnosti predstavlja prioritet privrede iDržave. Uraduje analizirana sezonalnost turističkog prometa u gradovima Srbije, a kao metoda korišten je model predviđanja primenjen na podatke sakupljene iz Republičkog zavoda za statistiku. Rezultati su prikazani analizom mesečnih podataka turističkog prometa u Beogradu, Novom Sadu i Nišu, u periodu od januara 2000. godine do decembra 2013. godine. Preciznost predviđanja određena je upoređivanjem RMSE i BIC instrumenata za merenje predviđanja. Na osnovu izabranih podataka urađeno je predviđanje turističkog prometa u pomenutim gradovima, a istraživanje je dovelo do zaključka da je odabrani model veoma primenjiv u praksi.

Ključne reči: predviđanje vremenskim serijama, eksponencijalni modeli, promet turista, Srbija

4 Profesor strukovnih studija, dr Nataša Papić-Blagojević, Visoka poslovna škola strukovnih studija, Srbija, Vladimira Ulica Perića Valtera br. 4, Telefon: +381 6417368 39, E-mail: npapic.blagojevic@gmail.com

5 Predavač, dr Aleksandra Vujko, Visoka poslovna škola strukovnih studija, Srbija, Vladimira Ulica Perića Valtera br. 4, Telefon: +381 6491426 45, E-mail: aleksandravujko@yahoo.com

6 Profesor strukovnih studija, dr Tamara Gajić, Visoka poslovna škola strukovnih studija, Srbija, Vladimira Ulica Perića Valtera br. 4, Telefon: +381 63565 544, E-mail: gajic tamara@yahoo.com 